\title{
STUDI PELEPASAN TERKONTROL TERHADAP NANOENKAPSULASI DIMETOKSI AMINO CALKON SEBAGAI DESAIN KANDIDAT SENYAWA ANTI KANKER YANG EFEKTIF
}

\author{
Mochamad Zakki Fahmi*, Hery Suwito, Shofi Yasmin Nurain, Yogi Putra Hidayatullah \\ Departemen Kimia, Fakultas Sains dan Teknologi \\ Universitas Airlangga \\ *email:m.zakki.fahmi@fst.unair.ac.id
}

Received 8 August 2016

Accepted 30 November 2016

\begin{abstract}
Abstrak
Enkapsulasi merupakan sebuah proses dimana partikel kecil dikemas dalam sebuah partikel yang lebih besar sehingga membentuk kapsul. Metode tersebut akan digunakan untuk memodifikasi calkon, senyawa anti kanker yang memiliki kelarutan dalam air sangat rendah, dengan menggunakan bovine serum albumin (BSA) sebagai enkapsulan. Modifikasi senyawa calkon ini dilakukan dengan mencampurkan larutan BSA dalam air dan larutan calkon dalam kloroform kemudian diultrasonikasi. Senyawa hasil sonikasi tersebut disebut produk nanoenkapsulan BSA-calkon. Produk selanjutnya diuji ketahanannya terhadap perubahan $\mathrm{pH}$, penambahan garam dan suhu. Produk kemudian dikarakterisasi menggunakan spektrofotometer UV-Vis, FTIR dan DLS. Proses nanoenkapsulasi dapat dikatakan berhasil dilakukan, ditunjukkan dengan produk nanoenkapsulan BSA-calkon yang dapat larut dalam air. Hasil karakterisasi menggunakan DLS menunjukkan bahwa produk nanoenkapsulan BSA-amino calkon memiliki rata-rata diameter partikel sebesar 457,5 $\mathrm{nm}$ dan 201,0 nm untuk produk nanoenkapsulan BSAdimetoksi amino calkon. Hasil FTIR dari nanoenkapsulan BSA-amino calkon memunculkan serapan gugus amida pada $1639,55 \mathrm{~cm}^{-1}$. Sedangkan pada nanoenkapsulan BSA-dimetoksi amino calkon, gugus amida muncul pada serapan $1635,69 \mathrm{~cm}^{-1}$.
\end{abstract}

Kata kunci: nanoenkapsulasi, calkon, bovine serum albumin dan anti kanker

\begin{abstract}
Encapsulation is a process where a small particles packaged in a larger particles and it forms into a capsule. This method intends to modify chalcone, an anticancer compound that have very low solubility in water. So it can't be applied into human bodies. This chalcone will be encapsulated by Bovine Serum Albumin. Modification of chalcone is carried out by mixing a BSA solution in water and chalcone solution in chloroform by an ultrasonication process. The product will be tested for the resistance of $\mathrm{pH}$, salt addition and temperature. The products also characterized using UV-Vis, FTIR and DLS instruments. Nanoencapsulation process was successfully do, it's indicated by the nanoencapsulan product that has a high solubility in water. The results of DLS indicate that products have an average particle size is $457,5 \mathrm{~nm}$ for BSA-amine chalcone and 201,0 $\mathrm{nm}$ for BSA-dimethoxy amine chalcone. FTIR results shows that nanoencapsulation BSAchalcone has amide groups, it showed by the absorption peak which raises at $1639,55 \mathrm{~cm}^{-1}$ for amine chalcone, and $1635,69 \mathrm{~cm}^{-1}$ for dimethoxy amine chalcone.
\end{abstract}

Keywords: nanoencapsulation, chalcone, bovine serum albumin and anti-cancer. 


\section{Pendahuluan}

Kanker adalah suatu penyakit yang disebabkan oleh pertumbuhan sel-sel jaringan tubuh secara tidak normal (Mangan, 2009). Survey WHO pada tahun 2013 menyatakan, penyakit kanker sebagai penyebab kematian nomor dua di dunia sebesar $13 \%$ setelah penyakit kardiovaskular (Kementerian Kesehatan Republik Indonesia, 2014). Berdasarkan Riset Kesehatan Dasar (Riskesdas) tahun 2013, prevalensi tumor atau kanker di Indonesia adalah 1,4 per 1000 penduduk. Dari riset juga diketahui bahwa kanker menduduki urutan ke tujuh sebagai penyebab kematian akibat penyakit di Indonesia setelah stroke, tuberklosis, hipertensi, cedera, perinatal dan diabetes melitus.

Sejauh ini, pengobatan kanker terutama di Indonesia memiliki banyak kendala seperti besarnya biaya yang dibutuhkan, efek samping dari pengobatan, dan jumlah obat kanker yang terbatas. Beberapa penderita kanker memilih pengobatan kemoterapi. Obat kemoterapi umumnya berupa kombinasi dari beberapa obat yang diberikan secara bersamaan dengan jadwal yang telah ditentukan. Selain membunuh sel kanker, obat kemoterapi juga berefek pada sel-sel sehat yang normal, terutama yang cepat membelah atau cepat tumbuh seperti rambut, lapisan mukosa usus dan sumsum tulang (Susanti dan Mula, 2010).

Sebelumnya, senyawa derivat dimetoksi amino calkon, yakni 2,3dimetoksi-4-aminocalkon, 2,4-dimetoksi4-aminocalkon, 2,5-dimetoksi-4aminocalkon telah dilaporkan berhasil disintesis oleh Suwito et al,. (2014). Dalam penelitian tersebut telah dijabarkan juga hasil uji sitotoksisitas senyawa hasil sintesisnya, dimana menunjukkan angka IC50 yang berarti bahwa senyawa tersebut memiliki potensi anti kanker yang rendah. Kelemahan yang dimiliki senyawa tersebut sama dengan senyawasenyawa anti kanker yang telah ada yaitu memiliki kepolaran yang rendah. Di dalam tubuh, senyawa non polar lebih sulit berdifusi ke dalam sitoplasma melalui dinding sel menuju protein target dibandingkan senyawa polar. Akibatnya aktivitas biologis dari senyawa tersebut tidak optimal (Campbell dan Norman, 2012).

Beberapa tahun terakhir, peneliti mulai mengembangkan aplikasi nanopartikel dalam bidang kesehatan, terutama aplikasinya sebagai pembawa obat (drug delivery) (Hans dan Lowman, 2002). Salah satu cara yang digunakan adalah menggunakan proses nanoenkapsulasi, yaitu mengemas obat dalam sebuah polimer dan dibuat dalam ukuran nano. Kelebihan dari nanoenkapsulasi antara lain dapat meningkatkan stabilitas obat, mengkontrol pelepasan obat dan dapat meningkatkan bioavailibilitas obat dalam tubuh karena ukurannya nano sehingga lebih mudah melalui membran permeabel pada sel (Pandey et al., 2005).

Dalam penelitian ini, akan dilakukan modifikasi senyawa dimetoksi amino calkon ini dengan mengemasnya dalam nanoenkapsulasi BSA (bovine serum albumin) sebagai nanocarrier supaya memiliki kepolaran yang lebih tinggi. Selanjutnya juga dilakukan uji kestabilan produk terhadap pengaruh $\mathrm{pH}$, garam dan suhu, serta karakterisasi produk enkapsulan.

\section{Metode Penelitian Alat dan Bahan}

Alat yang digunakan dalam penelitian antara lain: gelas ukur, gelas beaker, termometer, pengaduk magnetik, botol semprot, corong, spatula, kaca arloji, ultrasonikator Ultrasonic Homogenizer JY 92-IIDN, timbangan analisis Metler AE 200. Alat karakterisasi yang digunakan adalah spektrofotometer Shimadzu UV-Vis 1800, spektrofotometer (FTIR) Shimadzu dan Dynamic Light Scattering (DLS) Malvern Zetasizer Nano. 
Bahan-bahan yang digunakan dalam penelitian ini adalah bovine serum albumin (BSA), suksinat anhidrat, 2,3dimetoksi-4-aminocalkon, 2,4-dimetoksi4-aminocalkon, 2,5-dimetoksi-4aminocalkon, amino calkon, $\mathrm{NaOH}, \mathrm{HCl}$, $\mathrm{NaCl}$, aquades, membran dialisis (MWCO $1 \mathrm{kDa}$ ) dan kloroform.

\section{Prosedur Penelitian}

Proses nanoenkapsulasi calkon ke dalam BSA dilakukan dengan cara mencampurkan larutan BSA, anhidrida suksinat $(0,00026 \mathrm{mmol})$ dalam aquades, dan larutan calkon dalam kloroform. Tiga larutan tersebut kemudian diaduk menggunakan ultrasonikator selama satu menit tanpa jeda.

Hasil sonikasi selanjutnya diuji ketahananya terhadap perubahan $\mathrm{pH}$, adanya penambahan garam dan perubahan suhu. Uji ketahanan terhadap $\mathrm{pH}$ dilakukan pada rentang pH 3 hingga 12 . Pengaturan $\mathrm{pH}$ dilakukan dengan menambahkan sejumlah $\mathrm{HCl}$ dan $\mathrm{NaOH}$ hingga $\mathrm{pH}$ yang diinginkan tercapai. Larutan yang telah memiliki $\mathrm{pH} 3-12$ tersebut selanjutnya diamati pada 6 jam dan 24 jam setelah perubahan $\mathrm{pH}$. Produk nanoenkapsulan juga diuji kestabilannya terhadap adanya penambahn garam. Garam $\mathrm{NaCl}$ ditambahkan ke dalam $3 \mathrm{~mL}$ larutan nanoenkapsulan BSA-calkon dengan variasi konsentrasi garam yaitu $0,15,0,3$ dan $0,5 \mathrm{M}$. Tiga larutan tersebut dibandingkan dengan larutan BSA-calkon tanpa garam pada 6 dan 24 jam setelah penambahan garam ke larutan. Untuk pengujian kestabilan produk terhadap perubahan suhu, larutan dipanaskan hingga suhu mencapai $30^{\circ}, 40^{\circ}, 50^{\circ}$ dan $60{ }^{\circ} \mathrm{C}$ dan dilakukan selama 10 menit.

Uji pelepasan calkon dilakukan dengan menempatkan larutan nanoenkapsulan BSA-calkon ke membran dialisis $1 \mathrm{kDa}$. Perlakuan tersebut dilakukan dalam tiga variasi $\mathrm{pH}$, yaitu $\mathrm{pH} 4$ (asam), $\mathrm{pH} 7$ dan pH 10 (basa). Pada uji pelepasan calkon dari nanoenkapsulan BSA, pengambilan sampel dilakukan setiap 30 menit, 1 jam,
2,5 jam, 4 jam, 7 jam dan 24 jam sambil larutan diluar membran diaduk menggunakan pengaduk magnet selama 24 jam. Sampel selanjutnya diidentifikasi masing-masing konsentrasi per jamnya menggunakan instrumen spektrofotometer UV-Vis menggunakan lamda maksimal masing-masing calkon dan berdasarkan kurva kalibrasi calkon yang telah dibuat sebelumnya Konsentrasi calkon yang keluar dari membran dapat dihitung berdasarkan persamaan 1. Dengan $C t$ ' adalah nilai konsentrasi calkon keluar dari membran yang sebenarnya pada saat $\mathrm{t}$ waktu, $C t$ adalah rata-rata konsentrasi calkon yg diambil saat $\mathrm{t}$ waktu, $v$ adalah jumlah larutan yang diambil $(3 \mathrm{~mL})$, dan $V$ adalah volume total dari aquades dan buffer $(200 \mathrm{~mL})$. Nilai $C t$ ' yang telah didapatkan selanjutnya dibuat grafiknya dengan konsentrasi calkon sebenarnya $\left(\mathrm{Ct}^{\prime}\right)$ sebagai sumbu $\mathrm{x}$ dan waktu pengambilan sebagai sumbu y (Fahmi., (2014)

$$
C t^{\prime}=C t+\frac{v}{V} \sum_{0}^{i-t} C t
$$

\section{Hasil dan Pembahasan}

Sintesis nanoenkapsulasi BSA-calkon

Sintesis nanoenkapsulasi BSA-calkon dilakukan dengan cara mencampurkan larutan BSA, larutan anhidrida suksinat dan larutan calkon. Campuran larutan tersebut membentuk dua fasa yang tidak saling campur antara kloroform dan air. Selanjutnya campuran disonikasi selama satu menit tanpa jeda. Hasil dari proses sonikasi berupa larutan berbusa berwarna putih kekuningan dan hanya ada satu fasa larutan. Larutan didiamkan seharian hingga busa menghilang dan akan tampak larutan kuning bening yang larut air.

Seperti yang telah dijelaskan oleh Soares et al. (2007) dalam penelitiannya bahwa BSA memiliki beberapa gugus asam amino yang bersifat nonpolar seperti prolin dan histidin. Huang et al. (2004) 
juga mengemukakan bahwa pada struktur tiga dimensi BSA terdapat beberapa sisi nonpolar di dalamnya. Dalam penelitianpenelitian yang telah ada, disebutkan bahwa interaksi BSA dengan nanopartikel atau senyawa aktif dapat dipercepat menggunakan gelombang ultrasonik dengan metode transfer fasa, yaitu untuk menyatukan senyawa aktif yang terlarut di kloroform (tidak larut dalam air) ke dalam molekul BSA dengan cara berikatan pada sisi nonpolar pada BSA (Fahmi, 2014).

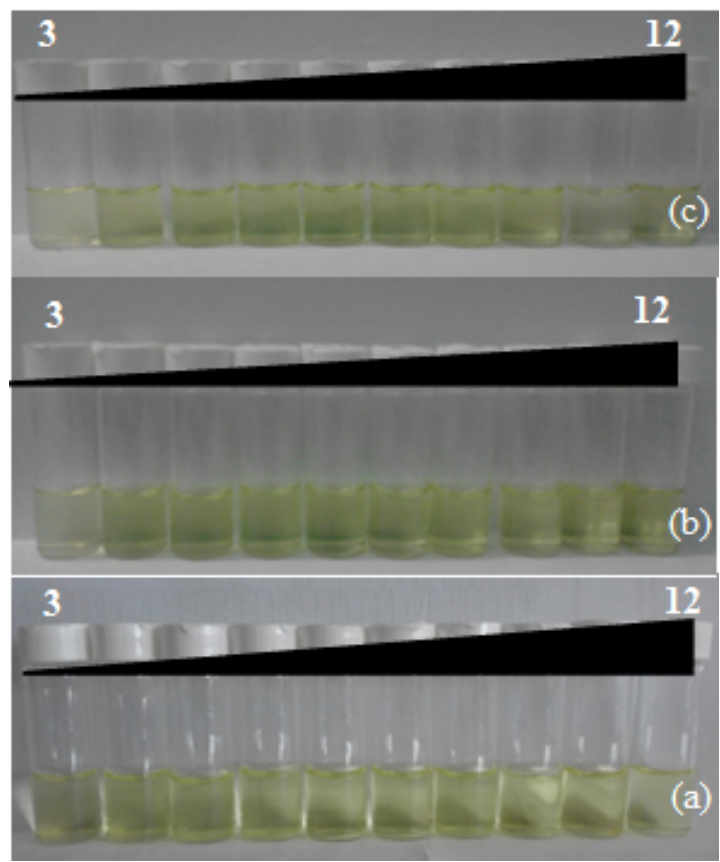

Gambar 1. Nanoenkapsulan BSA-amino calkon $\mathrm{pH} 3$ - 12 saat a) 0 jam, b) 6 jam dan c) 24 jam

\section{Uji kestabilan terhadap $p H$}

Data hasil uji kestabilan produk nanoenkapsulan BSA-calkon terhadap perubahan $\mathrm{pH}$ dapat diamati pada Gambar 1. Gambar 1 menunjukkan bahwa Pada waktu 6 jam, nanoenkapsulan BSA-amino calkon tampak mengalami perubahan warna pada larutan dengan $\mathrm{pH} 3$. Pada 24 jam, perubahan warna pada nanoenkapsulan BSA-amino calkon dengan $\mathrm{pH} 3$ semakin tampak jelas. Larutan yang mulanya berwarna kuning pudar berubah menjadi tidak berwarna.
Pada nanoenkapsulan BSA-dimetoksi amino calkon terdapat perubahan warna pada pH 3 setelah 6 jam (Gambar 2). Warna kuning pada larutan sedikit menghilang. Setelah 24 jam, warna kuning pada larutan semakin pudar hingga membentuk larutan tidak berwarna. Warna kuning pada larutan terbentuk karena adanya senyawa calkon yang pada dasarnya memang berwarna kuning. Pada saat pH 3 (asam) warna kuning menghilang dikarenakan adanya perubahan struktur pada calkon. Turunan calkon yang digunakan dalam penelitian ini adalah senyawa amino calkon. Gugus amina primer (NH2) pada calkon bersifat basa. Jika senyawa dengan gugus amina direaksikan dengan asam kuat $(\mathrm{HCl})$ maka akan menghasilkan garam ammonium (Brewster dan Eliel., 1953).

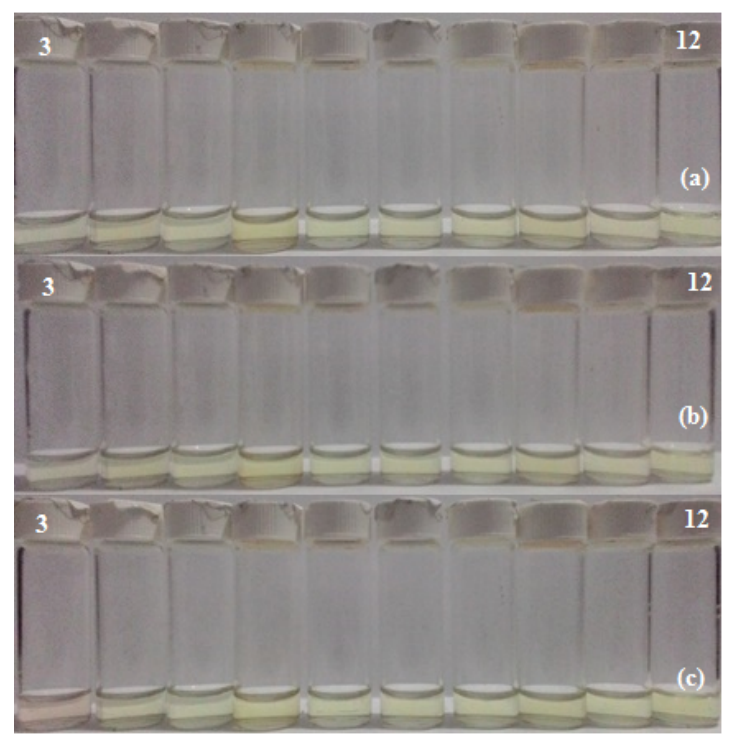

Gambar 2. Nanoenkapsulan BSAdimetoksi amino calkon $\mathrm{pH} 3$ - 12 saat a) 0 jam, b) 6 jam dan c) 24 jam

Uji kestabilan nanoenkapsulan BSAcalkon terhadap garam

Nanoenkapsulan diuji ketahanannya terhadap penambahan konsentrasi garam. Keempat larutan, 0, 0,15, 0,3 dan 0,5 M didiamkan selama 24 jam dan diamati pada 6 dan 24 jam setelah penambahan garam. Pada 6 jam pertama, nanoenkapsulan BSA-amino calkon 
terjadi perubahan pada konsentrasi $0,5 \mathrm{M}$ muncul endapan putih. Pada saat 24 jam, nanoenkapsulan dengan kadar garam 0,5 M semakin keruh dan terdapat semakin banyak endapan. Pada senyawa BSAdimetoksi amino calkon saat 6 jam belum ada perubahan apapun. Namun pada saat mencapai waktu 24 jam, pada larutan dengan konsentrasi garam sebesar $0,5 \mathrm{M}$ terdapat sedikit sekali endapan, sedangkan pada larutan lainnya masih tetap jernih.

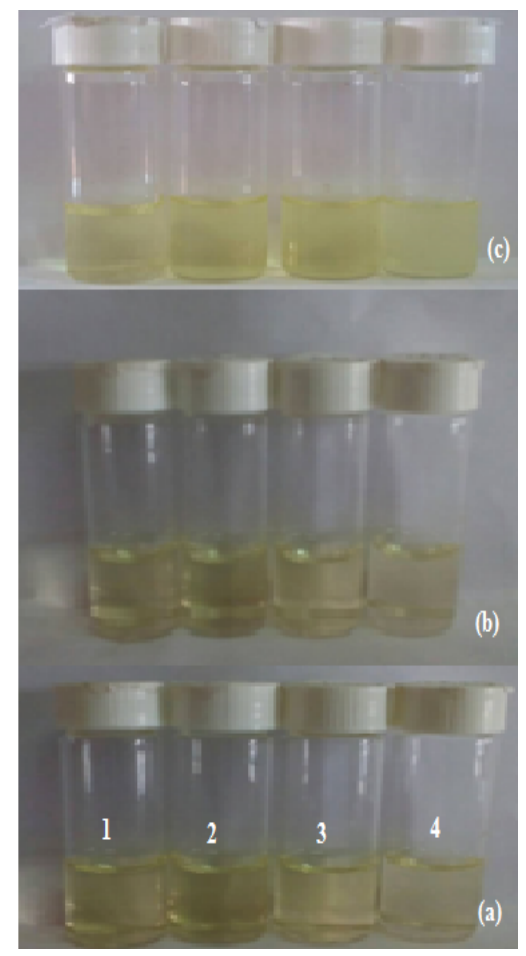

Gambar 3. Foto nanoenkapsulan BSAamino calkon dengan konsentrasi garam (1) $0 \mathrm{M}$, (2) $0,15 \mathrm{M}$, (3) 0,3 M, (4) 0,5 M pada a) 0 jam, b) 6 jam dan c) 24 jam

Peningkatan konsentrasi garam mengakibatkan diameter dari BSA semakin mengecil (Gao., et al, 2007). Keberadaan garam menjadi salah satu faktor kerusakan struktur pada BSA. Hal ini disebabkan karena ketika garam ditambahkan, maka garam tersebut akan bersaing dengan protein dalam mengikat air. Namun karena garam anorganik dapat lebih kuat menarik air, maka jumlah molekul air yang dapat diikat oleh protein akan semakin berkurang. Sehingga protein akan mengendap (Winarno, 2002).

Uji kestabilan nanoenkapsulan BSAcalkon terhadap suhu

Pada analisa kestabilan suhu terhadap nanoenkapsulan dengan memanaskan nanoenkapsulan BSA-amino calkon sampai mencapai suhu $30^{\circ}, 40^{\circ}$ dan $50^{\circ} \mathrm{C}$ selama 10 menit. Hasil analisa ini ditunjukkan pada Gambar 4. Pada larutan BSA-amino calkon tidak terjadi perubahan apapun pada suhu $30^{\circ}$ hingga $50^{\circ}$ C. Begitu pula pada larutan BSAdimetoksi amino calkon, tidak terjadi perubahan apapun.

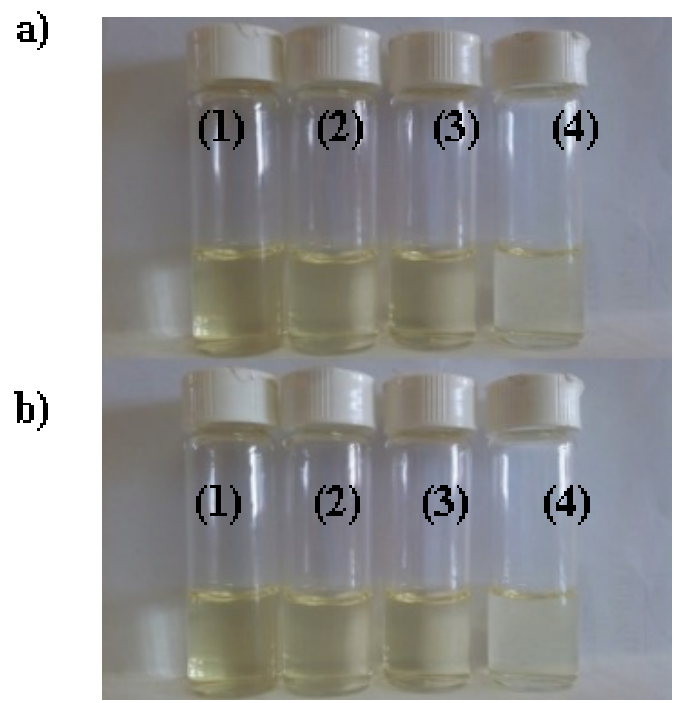

Gambar 4. Foto nanoenkapsulan BSAdimetoksi amino calkon dengan pemanasan hingga suhu (1) $30^{\circ} \mathrm{C}$, (2) 40 ${ }^{\circ} \mathrm{C}$, (3) $50{ }^{\circ} \mathrm{C}$, (4) $60{ }^{\circ} \mathrm{C}$ pada sebelum a) dan setelah pemanasan $b$ ).

Salah satu faktor denaturasi protein adalah suhu. Panas dapat memecah ikatan hidrogen pada protein. Protein biasanya akan rusak dan mengendap jika dipanaskan pada suhu diatas $60^{\circ} \mathrm{C}$ (Alais dan Linden., 1991). Pada hasil penelitian, pemanasan hingga suhu $60{ }^{\circ} \mathrm{C}$ tidak mengakibatkan perubahan apapun. Dapat disimpulkan bahwa nanoenkapsulan dapat 
bertahan dalam suhu tubuh manusia yang normalnya $36-37^{\circ} \mathrm{C}$.

Uji pelepasan nanoenkapsulan BSAcalkon

Dari penentuan lamda maksimum menggunakan spektrofotometer uv-vis, didapatkan lamda maks dari senyawa amino calkon adalah $312 \mathrm{~nm}$. Selanjutnya lamda maks digunakan untuk mencari absorbansi larutan standar, dihasilkan kurva kalibrasi dengan persamaan regresi yaitu $y=1916,6 x+0,0038$ yang digunakan dalam penentuan konsentrasi dari calkon. Hasil uji pelepasan amino calkon dari nanoenkapsulan BSA dapat dilihat dari Gambar 5.

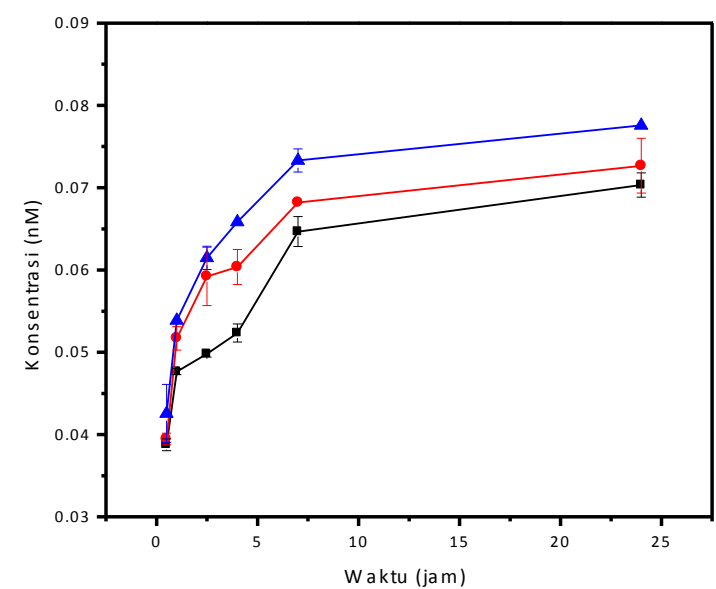

Gambar 5. Grafik uji pelepasan amino calkon pada pH 4 (hitam), 7 (merah), dan 10 (biru).

Nanoenkapsulan BSA-dimetoksi amino calkon juga dibuat kurva standarnya dengan konsentrasi larutan standar sebesar konsentrasi $3.10^{-6}, 5.10^{-6}$, $10^{-5}, 3.10^{-5}$ dan $5.10^{-5}$ M. Dari absorbansi larutan standar tersebut, didapatkan persamaan regresi dengan kurva kalibrasi yaitu $y=16282 x-0,0291$. Hasil uji pelepasan dimetoksi amino calkon dari nanoenkapsulan BSA dapat dilihat dari Gambar 6.

Jika dilihat pada hasil pengamatan uji pelepasan kedua senyawa calkon di atas, dapat diketahui bahwa uji pelepasan calkon paling maksimal terjadi saat pada $\mathrm{pH} 4$, selanjutnya $\mathrm{pH} 7$ dan terakhir $\mathrm{pH}$ 10. Hal tersebut dapat terjadi di karena pada saat $\mathrm{pH} 4$ (asam) struktur klaster pada BSA mengembang, sehingga menimbulkan adanya rongga-rongga yang dapat dilewati oleh calkon. Pada saat $\mathrm{pH}$ 10 (basa), struktur klaster pada BSA akan semakin menyempit sehingga calkon yang terenkapsulasi dalam BSA sulit untuk keluar dari enkapsulasi BSA (Fahmi et al., 2014).

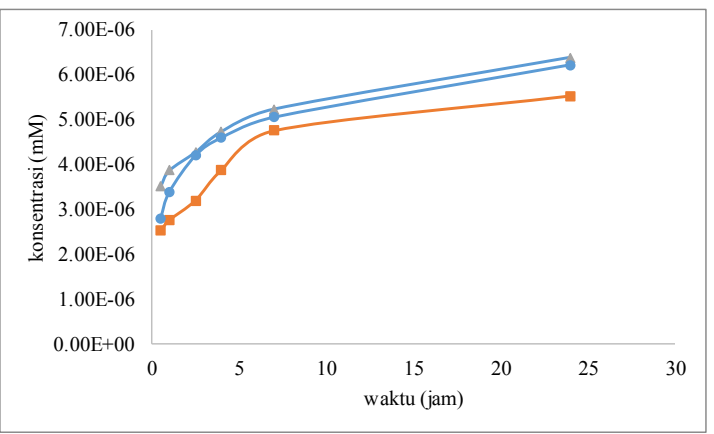

Gambar 6. Grafik uji pelepasan dimetoksi amino calkon pada $\mathrm{pH} 4$ (merah), 7 (biru), dan 10 (hijau). 


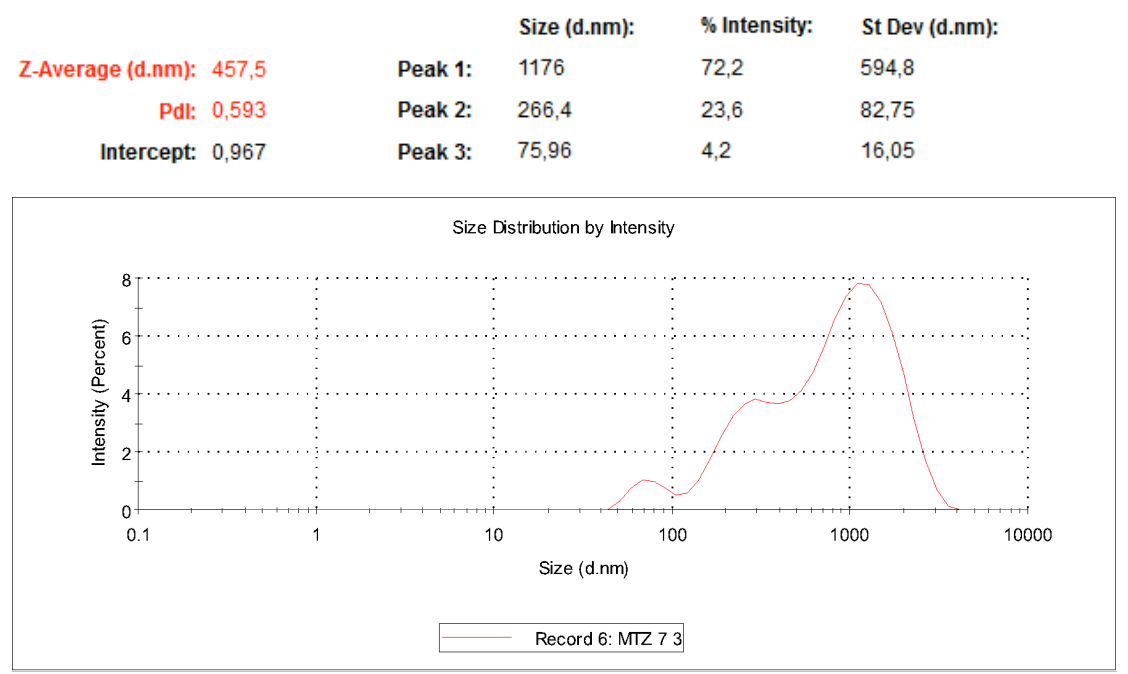

Gambar 7. Spektra hasil analisa DLS nanoenkapsulan BSA-amino calkon

Karakterisasi nanoenkapsulan BSA- nm sebanyak 23,6\%. Puncak terakhir calkon menggunakan dynamic light menunjukkan partikel berukuran 75,96 scattering $(D L S)$

Karakterisasi menggunakan DLS ini bertujuan untuk mengukur diameter partikel yang terbentuk. Berdasarkan hasil karakterisasi senyawa menggunakan DLS ini didapat grafik intensitas ukuran partikel (Gambar 7). Terdapat tiga puncak utama dari hasil pengukuran menggunakan DLS di atas. Peak pertama dan yang paling tinggi menunjukkan adanya partikel berukuran $1176 \mathrm{~nm}$ yang memiliki intensitas sebesar 72,2\%. Puncak kedua menunjukkan partikel yang memiliki ukuran diameter sekitar 266,4 $\mathrm{nm}$ dengan intensitas 4,2\%. Dari ketiga puncak tersebut, didapatkan rata-rata ukuran partikel nanoenkapsulan BSAamino calkon ini adalah 457,5 $\mathrm{nm}$.

Gambar DLS untuk BSA-dimetoksi amino calkon dapat dilihat pada Gambar 8. Dari spektra tersebut dapat kita lihat bahwa ada tiga peak yang Nampak. Pertama yaitu peak yang menunjukkan ukuran diameter partikel 246,8 nm dengan intensitas 94,6 \%. Peak kedua menunjukkan banyaknya particle yang berukuran $42,39 \mathrm{~nm}$ memiliki intensitas sebanyak 3,1\%. Dan peak yang terakhir

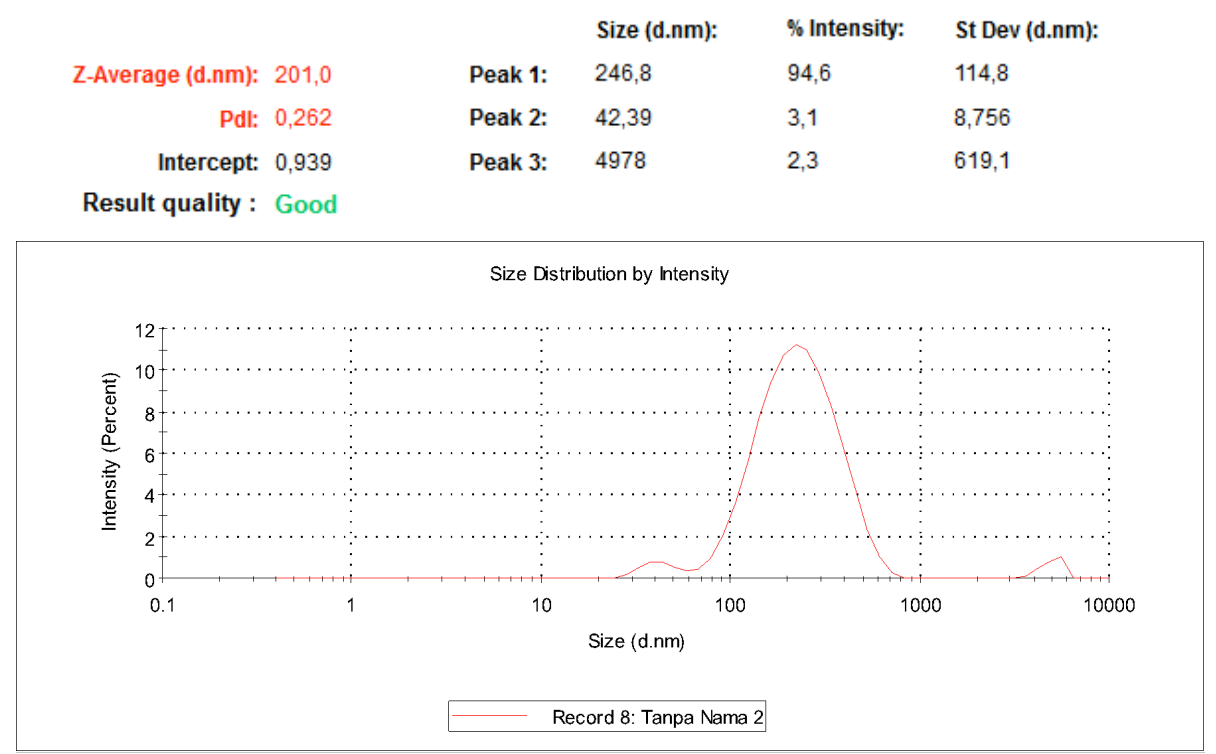

Gambar 8. Spektra hasil analisa DLS nanoenkapsulan BSA-dimetoksi amino calkon 


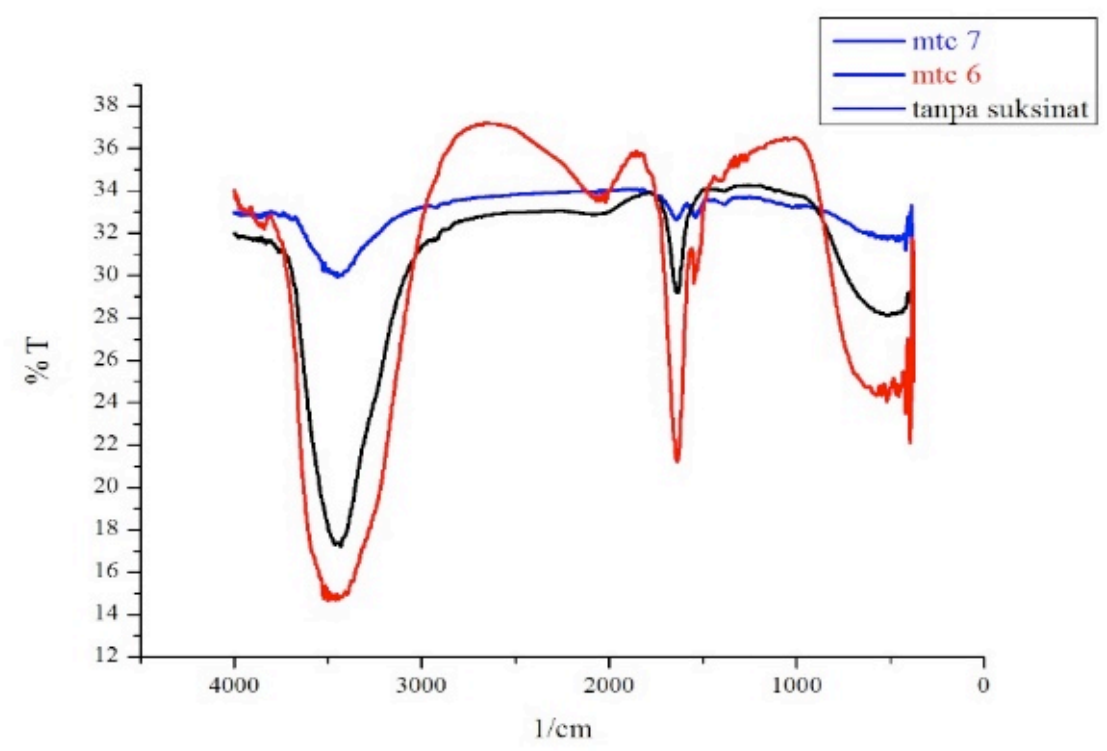

Gambar 9. Spektra hasil analisa DLS nanoenkapsulan BSA-dimetoksi amino calkon

memunjukkan ada 2,3\% partikel yang berukuran cukup besar yaitu $4978 \mathrm{~nm}$. Jika dirata-rata, maka didapatkan diameter rata-rata partikel nanoenkapsulan BSA-dimetoksi amino calkon sebesar $201 \mathrm{~nm}$. Dalam penelitian Fahmi et al., (2014) disebutkan bahwa perbandingan konsentrasi BSA dengan senyawa aktif mempengaruhi ukuran partikel yang terbentuk. Semakin besar konsentrasi BSA yang digunakan dalam campuran, semakin kecil pulan ukuran nanopartikel yang terbentuk.

Karakterisasi nanoenkapsulan BSAcalkon menggunakan FTIR

Berdasarkan hasil karakterisasi menggunakan FTIR, didapatkan gugus amida pada kedua senyawa. Gugus amida yang terdeteksi dapat muncul akibat adanya ikatan antara gugus fungsi BSA dengan anhidrida suksinat.Terbentuknya gugus amida dibuktikan oleh spektra FTIR pada serapan 1639,55 cm-1 pada senyawa nanoenkapsulasi BSA-amino calkon dan pad aserapan 1635,69 cm-1. Gugus amida sendiri menandakan adanya ikatan antara anhidrida suksinat sebagai agen penaut silang dengan BSA.

\section{Kesimpulan}

Nanoenkapsulasi calkon ke dalam BSA dapat dilakukan melalui proses sonikasi larutan BSA dan anhidrida suksinat serta larutan calkon. Hal tersebut dibuktikan oleh adanya calkon yang terlarut dalam air setelah proses transfer fasa.Nanoenkapsulan BSA-calkon dapat tahan pada $\mathrm{pH} 5-12$, penambahan garam hingga $0,3 \mathrm{M}$ dan pemanasan hingga suhu $60^{\circ} \mathrm{C}$. Berhasilnya proses nanoenkapsulasi BSA-calkon juga didukung oleh adanya gugus amida yang teridentifikasi dalam spektra FTIR. Pada puncak serapan gugus amida pada $1639,55 \mathrm{~cm}^{-1}$. Sedangkan nanoenkapsulan BSA-dimetoksi amino calkon muncul pada 1635,69 $\mathrm{cm}^{-1}$. Ukuran partikel rata-rata pada nanoenkapsulan BSA-calkon juga sudah mencapai diameter $457,5 \mathrm{~nm}$ untuk amino calkon dan 201,0 nm untuk dimetoksi amino calkon. Dari hasil uji pelepasan terkontol, dapat diketahui bahwa pada $\mathrm{pH}$ 4, calkon dalam BSA dapat lebih efektif keluar dari enkapsulan dibandingkan jika dalam keadaan basa ataupun netral.

Nanoenkapsulasi calkon ke dalam BSA dapat dilakukan melalui proses sonikasi larutan BSA dan anhidrida suksinat serta larutan calkon. Hal tersebut 
dibuktikan oleh adanya calkon yang fasa. Nanoenkapsulan BSA-calkon dapat tahan pada $\mathrm{pH} 5-12$, penambahan garam hingga $0,3 \mathrm{M}$ dan pemanasan hingga suhu $60^{\circ} \mathrm{C}$. Berhasilnya proses nanoenkapsulasi BSA-calkon juga didukung oleh adanya gugus amida yang teridentifikasi dalam spektra FTIR. pada puncak serapan gugus amida pada $1639,55 \mathrm{~cm}^{-1}$. Sedangkan nanoenkapsulan BSA-dimetoksi amino calkon muncul pada $1635,69 \mathrm{~cm}^{-1}$.

\section{Daftar Pustaka}

Brewster, J. H., \& Eliel, E. L. (1953) Carbon-Carbon Alkylations with Amines and Ammonium Salts. Organic Reactions.

Campbell, G.S., Norman, J.M. (2012) An introduction to environmental biophysics, Springer Science \& Business Media.

Fahmi, M. Z., Ou, K. L., Chen, J. K., Ho, M. H., Tzing, S. H., and Chang, J. Y. (2014) Development of bovine serum albumin-modified hybrid nanoclusters for magnetofluorescence imaging and drug delivery, $R S C$ $A d v, 4(62), 32762-32772$.

Hans, M., Lowman, A. (2002) Biodegradable nanoparticles for drug delivery and targeting, Current Opinion in Solid State and Materials Science, 6(4), 319-327.

Huang, B. X., Kim, H. Y., \& Dass, C. (2004) Probing three-dimensional structure of bovine serum albumin by chemical cross-linking and mass spectrometry, $J$. Am. Soc. Mass Spectrom, 15(8), 1237-1247.

Mangan, Y. (2009) Solusi Sehat Mencegah \& Mengatasi Kanker: AgroMedia, 1-4. terlarut dalam air setelah proses transfer Ukuran partikel rata-rata pada nanoenkapsulan BSA-calkon juga sudah mencapai diameter $457,5 \mathrm{~nm}$ untuk amino calkon dan 201,0 nm untuk dimetoksi amino calkon. Dari hasil uji pelepasan terkontol, dapat diketahui bahwa pada $\mathrm{pH}$ 4, calkon dalam BSA dapat lebih efektif keluar dari enkapsulan dibandingkan jika dalam keadaan basa ataupun netral.

Pandey, R., Ahmad, Z., Sharma, S., Khuller, G. (2005) Nanoencapsulation of azole antifungals: potential applications to improve oral drug delivery, Int. J. Pharm, 301(1), 268-276.

Soares, S., Mateus, N., and De Freitas, V. (2007) Interaction of different polyphenols with bovine serum albumin (BSA) and human salivary $\alpha$-amylase (HSA) by fluorescence quenching, J. Agric. Food Chem, 55(16), 6726-6735.

Susanti, L., Mula, T. (2010) Karakteristik Mual Dan Muntah Serta Upaya Penanggulangan Oleh Penderita Kanker Yang Menjalani Kemoterapi. Fakultas Keperawatan: USU.

Suwito, H., Pudjiastuti, P., Fanani, M.Z., Kimata-Ariga, Y., Katahira, R., Kawakami, T., Puspaningsih, N.N.T. (2014) Design and Synthesis of Chalcone Derivatives as Inhibitors of the Ferredoxin-Ferredoxin-NADP+ Reductase Interaction of Plasmodium falciparum: Pursuing New Antimalarial Agents, Molecules, 19(12), 21473-21488. 
